\title{
The Added Value of Brand Alliances in Higher Education
}

This is a pre-publication manuscript of the paper accepted for publication in the Journal of Business Research Special Issue on HE Branding

For published version, please visit: http://www.journals.elsevier.com/journal-of-business-research/

Stavros P. Kalafatis

Professor of Business Marketing, Kingston Business School, Kingston University, Kingston Hill, Kingston-upon-Thames, Surrey KT2 7LB, UK; Tel: +44 (0) 208417 5121; email:

kalafatis@kingston.ac.uk

Lesley Ledden ${ }^{\S}$

Kingston Business School, Kingston University, Kingston Hill, Kingston-upon-Thames, Surrey KT2 7LB, UK; Tel: +44 (0) 208417 5456; email: 1.ledden@kingston.ac.uk

Debra Riley

Kingston Business School, Kingston University, Kingston Hill, Kingston-upon-Thames, Surrey KT2 7LB, UK; Tel: +44 (0) 208417 5404; email: d.riley@ kingston.ac.uk

Jaywant Singh

Kingston Business School, Kingston University, Kingston Hill, Kingston-upon-Thames, Surrey KT2 7LB, UK; Tel: +44 (0) 208417 5158; email: j.singh@ kingston.ac.uk

$\S$ Corresponding author 


\begin{abstract}
This study examines perceptions of brand alliances, in the form of dual degrees, between UK universities. Signalling theory and attitude accessibility are applied to test for evidence of added value of dual degrees bearing the names of two universities compared to single degrees. The results support the main hypothesis that perceptions of added value of a dual degree initiated by a high (low) ranked context university decline (increase) in line with the ranking of a lower (higher) rank partner university. The findings reveal interaction effects between the rank position of the initiating university and the evaluation criteria. Name-order effects explain the higher perceived value of a dual degree between high-and-low ranked universities compared to a dual degree between low-andhigh ranked universities. In addition to being the first study to examine brand alliances in the UK HE domain, the study makes a number of contributions to the general brand alliance literature and provides managerial guidelines.
\end{abstract}

\title{
Keywords:
}

Higher Education

Brand alliances

Value perceptions

Signalling theory

Attitude accessibility

Name-order effects 


\section{Introduction}

Growing competition and globalisation, reduced government funding, and increased efforts to recruit international students have fuelled the 'marketisation' of the UK higher education. The adoption of business models by universities has proponents and detractors (see debate in Curtis, Abratt and Minor, 2009 and Hemsley-Brown and Goonawardana, 2007). The former contend that marketisation provides an appropriate platform for universities to engage with university audiences (Carvalho and Mota, 2010; Ng and Forbes, 2009), while the latter claim the resulting commoditisation of education results in an instrumental view of education (Gibbs, 2002 and 2007; Molesworth, Nixon and Scullion, 2009). This study does not address this debate and accepts the adoption of commercial practices by UK universities (Brookes, 2003; Chapleo, 2010a; Curtis et al., 2009; Melewar and Akel, 2005; Wæraas and Solbakk, 2009). The research focuses on branding as a strategy to create competitive advantage and manage the global and governmental challenges facing the UK higher education (HE) sector (Hemsley-Brown and Goonawardana, 2007; Pinar, Trapp, Girard and Boyt, 2011).

There are a number of reviews on the relevance, management and effectiveness of branding in higher education (e.g., Bennett and Ali-Choudhury, 2009; Chapleo, 2011; Hemsley-Brown and Goonawardana, 2007; Hemsley-Brown and Oplatka, 2006; Khanna, Jacob and Yadav, 2014; Pinar et al., 2011). Although the growing importance of branding in $\mathrm{HE}$ is recognised (see special issue of Journal of Marketing for Higher Education 2014), the paucity of empirical evidence is notable. Hemsley-Brown and Oplatka (2006; p. 333) conclude that 'although there have been a number of studies that examine image and reputation, the notion of branding has barely made its mark in higher education.' Hemsley-Brown and Goonawardana (2007; p. 943) state that 'the research on higher education branding is at a pioneer stage with much still needed both from an exploratory and strategic perspective' and Khanna et al. (2014; p. 124) emphasise the need to 'research the factors that help to create and build brands'. Although collaborative branding between HE organisations, 
(or between HE and commercial partners) is increasing in the UK and abroad, this area of strategic branding is overlooked by the nascent HE branding literature.

Brand alliance activities in higher education range from short term initiatives (e.g., Bath Spa University and Bath City Football Club co-advertising an event), to ongoing cause-brand alliances (e.g., Plymouth University and Brain Tumour Research) to co-branded product offerings (e.g., "The Producing Animation Course" created by Aardman Animation and University of the West of England). Universities choose to collaborate for many reasons, including curriculum innovation, increased mobility (of student and staff), improved reputation, adding value (in terms of experiences, content and outcomes) to student degrees, and market expansion. For example, Bournemouth University and the Arts University Bournemouth have a joint initiative to offer creative and technical expertise in multiple departments at both universities. The aim is to provide commercial outlets and links to industry for students, graduates and academic staff. Kingston University and Russian Presidential Academy of National Economy and Public Administration (RPANEPA) offer a joint MBA that provides students with an opportunity to gain a comparative understanding of business practices in the UK and Russia, encourage cross-fertilization of faculty, and expands the geographic reach of both institutions. Despite these market activities, only two scholarly references to brand alliances in higher education have been identified. Hemsley-Brown and Goonawardana (2007) discuss a brand alliance (in the form of collaborative promotional activities) between the British Council and UK universities. The effectiveness of these promotions is supported by students' use of material from the British Council website in their university applications. Chan and Cheng (2012) investigate Hong Kong universities co-branding with hotels, finding a strong correlation between the perceived fit of the brands and consumer evaluations of the alliance. This relationship increases with an individual's familiarity with the brands. The focus of the current study is on brand alliances that lead to dual (also referred to as joint) degrees, i.e. degrees awarded by and bearing the names of more than one university. 
Dual degrees have risen in response to shifts in students' needs and changes to the economic environment and are found on the websites of many UK Universities; for example, Aston Business School, Anglia Ruskin University, Coventry University, Kings College London, LSE, University of Aberdeen Business School, and University of Kent. Accepting that the primary aim of universities is to create value for students (Chung and McLarney, 2000), this paper compares and contrasts perceptions of value from a single degree (no brand alliance) with those of a comparable dual degree (brand alliance) in two studies. The research makes three important contributions. First, the studies offer empirical evidence for brand alliance perceptions in HE, conceptually linking the university's brand equity (approximated through national rankings) to the value perceptions of its customer base. The study applies seven equity levels of alliance pairing, as compared to the traditional high/low dichotomy of most research (e.g., Washburn, Till \& Priluck, 2004). The results reveal substantive difference between levels and suggest that over-simplified brand equity pairings (such as high vs low) can lead to confounding effects. Second, although added value is often cited as a principal reason for pursuing a brand alliance (Erevelles, Horton and Fukawa 2008; Helmig, Huber and Leeflang 2008; Norris, 1992), it received little research attention. The current study addresses this gap. Finally, the paper takes a multidimensional view of brand alliances, examining individual elements of customer value. Only two studies of brand alliances have used multidimensional measures to date (James, Lyman and Foreman 2006; Kalafatis, Riley and Singh, 2014). Considering multiple dimensions allows for a more nuanced view of the alliance, in keeping with literature on brand personality and brand equity, which highlight the multiple components of a brand (Aaker, 1997; Keller, 1993).

The article proceeds as follows. Following this introduction, Section 2 describes the conceptual framework for assessing a university dual degree and presents the underlying hypotheses, starting with a discussion of the literature on brand alliances. Section 3 outlines the two studies and Section 4 presents the analysis of value perceptions of the single and dual degree 
offering for the collaborating universities. The paper closes with a summary discussion and outlines implications for marketing theory and practice.

\subsection{Theoretical background and conceptual development}

\subsection{Brand Alliances}

The literature identifies various forms of brand alliances such as joint sales promotions, advertising alliances that feature two brands together in an advertisement, bundled offerings where two or more products are offered together for a special price, ingredient branding where two brands at different value chain steps label a product jointly (e.g., IBM and Intel), and horizontal cobranding, where a new product is branded by two producers at the same step in the value chain (Helmig, Huber and Leeflang, 2007). There is debate among authors as to whether a brand alliance must include both a physical and symbolic association of brand names (Rao and Rueckert, 1994; Erevelles et al., 2008). Although some authors apply a strict nomenclature for co-brands vs brand alliances, the majority of studies consider the terms to be equivalent. This study considers a product offering (the dual degree) co-branded and promoted by both partners. The terms brand alliance and co-brand are used interchangeably in this research.

Research on brand alliances starts with conceptual work highlighting the potential benefits (Norris, 1993) and quickly moves to the mental processes that drive brand evaluations (Hillyer and Tikoo, 1995; Rao and Ruekert, 1994). Subsequent empirical research draws from a number of different theoretical frameworks to explore how consumers form perceptions of a brand alliance; including composite concept formation (Park, Jun and Shocker, 1996), information integration theory and attitude accessibility (e.g., Simonin and Ruth, 1998), signalling theory (e.g., Rao, Qu and Ruekert, 1999), associative memory networks (e.g., Samu, Krishnan and Smith, 1999) and adaptive learning (e.g., Cunha, Forehand and Angle, 2015). As signalling theory, information integration theory, and associative memory networks represent the lion's share of empirical work on brand alliances, each domain is addressed briefly. 
Signalling theory explains how attitudes are formed in relation to unobservable product/service quality under conditions of information asymmetry. The buyer has less information about the product than the seller and therefore makes inferences about the unobservable quality of a product (e.g., durability, performance) from the information provided.

Quality information is signalled via low/high introductory price, warranties, money back guarantees, investment in reputation, volume of advertising, and brand name (see Kirmani and Rao, 2000 for a debate and classification of signals). The effectiveness of a quality signal hinges on consumer (and firm) perceptions that deception (i.e., claiming higher quality than is actually true) is economically unattractive. Rao et al. (1999) show that co-branded products provide an enhanced quality signal compared with single-branded products. A number of studies find enhanced perceptions for an unknown brand when paired with a well-known, high quality partner (Fang and Misra, 2002; Vaidyananthan and Aggarwal, 2000). McCarthy and Norris (1999) find that an enhanced quality signal is more often present for the weaker brand partner than for the stronger one. Gammoh, Voss and Chakraborty (2006) find that the signalling role of a strong brand partner varies depending on the strength of the co-branded product message and the degree of cognitive effort required. When cognitive requirements are low, and the information presented about the brand alliance is high, the stronger brand serves to endorse the veracity of the claims. When cognitive requirements are high and little additional information is present, the stronger partner signals quality/functionality for the lesser known brand. Voss and Gammoh (2004) examine the effect of multiple brand allies, finding that multiple allies do not increase quality perceptions of a partner brand over a single brand ally. Researchers explored the signalling effect of a brand alliance across marketing channels (Delgaldo-Ballester and Hernandez-Espallardo 2008), marketing actions (Fang, Gammoh and Voss, 2013; Besharat, 2010) and product categories (Desai and Keller, 2002; Lebar, Buehler, Keller, Sawicka, Aksehirili and Keith, 2005). Although not unequivocal, these studies find that a brand with high awareness and strong quality perceptions usually acts as a positive signal 
to consumers, influencing perceptions of both the brand alliance offering and the lesser known partner brand.

Information integration theory describes the process by which attributes are combined in a weighted assessment to form beliefs or attitudes (Anderson, 1981). New attitudes or beliefs are formed or modified as people interpret, evaluate and integrate new information with pre-existing beliefs or attitudes. Attitudes toward an object, particularly if they are easily brought to mind, can affect an individual's perceptions with information processing biased in the direction implied by the attitude (Houston and Fazio, 1989). Attitude accessibility is by exposure to associated cues such as visual or verbal stimuli (Fazio, 1986). Drawing on models applied to brand extensions, Simonin and Ruth (1998) show that a brand alliance is positively influenced by positive prior attitudes toward each partner brand, as well as positive perception of the brand fit and the product fit of the partner brands. The term "fit" refers to customers' perceptions of the compatibility or similarity of the two product categories and the brand concepts of the partner brands. In addition, attitudes toward the alliance spill over and influence post-exposure attitudes toward the partner brands. Although less familiar brands have a weaker influence on the attitude formed by consumers towards the cobranded product, they receive a greater spillover from the brand alliance than does the stronger, more familiar brand. Simonin and Ruth's model is widely replicated and extended to consider additional factors such as country of origin effects (Bluehelhuber, Carter and Lambe, 2007), product-brand fit (Bouten, Snelders and Hultink, 2011), product involvement (Huber, 2005) and buyer characteristics (Helmig et al., 2008). Overall, these studies suggest that a brand alliance is more successful if there is high awareness and high perceived quality of the partner brands and if the fit between the partner brands and their product categories is high.

In contrast to a focus on signalling or salience as the trigger for developing brand associations, associative network models propose that concepts linked in memory form both direct connections with one another and indirect secondary connections with other shared associations (Anderson and Bower, 1973). Associative network models explain why a new brand might link 
with external actors (such as other brands, events, causes, people, etc.) that already possess valued associations in the hope that these associations will transfer to the new brand (Keller, 2003). In the context of brand alliances, research shows such transfers between partners do not appear to require in-depth deliberation (Galli and Gorn, 2011) and can result in positive (Park, Milberg and Lawson, 1991) or negative (Voltolato and Unnava, 2006) associations. Associative network models assume that partnerships between brands disproportionally affect the less-known brand since it is relatively empty of associations and is primed to receive them from an established brand (Levin and Levin, 2000, Washburn, Till and Priluck, $2000 \&$ 2004). An alternative model of association development, adaptive learning, proposes that each partner brand may influence the degree to which the other brand is seen as responsible for the benefits the new co-branded product delivers, and could cause a dominant established brand to undermine the benefits of co-branding for the less-known brand (Cunha et al., 2015).

\subsection{Conceptual framework and hypotheses}

This study is grounded on attitude accessibility and signalling theory and the underpinning concept is students' perceptions of value. We denote the university that initiates an alliance leading to a dual degree as the context brand and the collaborating university as the partner. According to Doyle and Stern (2006, p. 166) 'Added values - the subjective beliefs of customers - are at the heart of building successful brands ... or the level of perceived quality compared to competitors is one of the main characteristics of a successful brand'. This study proposes that value perceptions of a successful dual degree (brand alliance) are significantly higher (added value) to those of an equivalent degree offered by the context university. Attitude accessibility theory asserts that a quality assessment is based on salient brand attitudes that are easily accessible by the target audience. Gray, Fam and Llanes (2003; p.109) argue that 'Universities need to understand ...the perceived value of core and augmented elements of their offerings if they are to develop globalised brands'. Pinar et al. (2011) place students' perceptions of value at the nucleus of their university brand ecosystem framework. They consider perceptions of value to be derived from core (e.g., 
teaching and learning), augmented (e.g., social activities) and supporting (e.g., family and employers) elements.

Studies of perceived value converge on the view that the construct comprises two components, benefits and sacrifices (Babin and James, 2010; Woodall, 2003; Zeithaml, 1988), each representing a number of dimensions (Babin and James, 2010; Sánchez-Fernández and IniestaBonillo, $2007 \& 2009)$. Drawing on these studies, we conceptualise value in terms of five benefits: functional, emotional, epistemic, social and image; and two sacrifices, i.e. time and money (Ledden, Kalafatis and Samouel, 2007; Ledden, Kalafatis and Mathioudakis, 2011). Functional value represents benefits associated with employment and career goals; emotional value accounts for the sense of pride and self-achievement in taking a degree; epistemic value reflects learning and knowledge acquisition; social value is derived from the views of important others such as family, friends and future employers; and image value is the reputational benefit from studying at a highly regarded university. Time sacrifice is the loss of time to spend on pleasure activities, and monetary sacrifice relates to financial costs such as fees, accommodation and textbooks.

The problem facing prospective students is lack of information about the quality of the dual degree (information asymmetry). The rankings of the context and partner universities act as proxy signals of their respective brand equity and provide the assessment platform for the quality of the dual degree. Rankings have been shown to be the most reliable measure of a university's brand equity, as opposed to softer brand metrics (Bunzel, 2007; Chapleo, 2010b and 2011). Brand alliances between high equity brands are more likely to be successful (e.g., Simonin and Ruth, 1998; Washburn et al., 2000 and 2004), thus leading to the following hypotheses:

$\mathrm{H}_{1 \mathrm{a}}$ : Perceptions of the added value of a dual degree initiated by a high ranked context university decline in line with the ranking of a lower rank partner university.

$\mathrm{H}_{1 \mathrm{~b}}$ : Perceptions of the added value of a dual degree initiated by a low ranked context university increase in line with the ranking of a higher rank partner university 
We attempt to delineate the above hypotheses by comparing perceptions of added value in brand alliances between transposed cluster memberships, e.g. highest with lowest vs lowest with highest rank partnerships. Two streams of research inform our deliberations. The first is grounded in primacy effects. Studies of composite branding (Park et al., 1996) and ingredient co-branding (Desai and Keller, 2002; Venkatesh and Mahajan, 1997) suggest that the order of brand presentation (e.g. A-B vs B-A) influences customer perceptions. However in both co-branding formats, one brand has clear ownership of the product; for example, "Godiva cake mix by Slim-Fast" (Park et al., 1996) and "Tide detergent with Irish Spring scented bath soap" (Desai and Keller, 2002). This header + modifier approach does not apply when two brands are equally presented. More recently, $\mathrm{Li}$ and $\mathrm{He}$ (2013) argue that the order of presentation signals the relative power, responsibilities, and control of partner brands in an alliance, with the first brand having stronger signalling power. Arguing that normal practice dictates that the stronger more dominant brand precedes the other, they find a moderating effect of brand order on consumer attitudes to partners in international brand alliances. Consequently we expect differential evaluations of brand alliances depending on the presentation of the rank order of the partner universities. For a given alliance, perceptions will be higher when the name of the higher rather than the lower ranked university is presented first. However, this prediction is based on research focusing on overall evaluations rather than value added in brand alliances.

A review of research on the impact of asymmetrical brand alliances helps refine the above supposition. Kalafatis, Remizova, Riley and Singh (2012) examine how partners in a brand alliance accrue economic, functional and psychological benefits and find that in higher-lower equity partnerships, the lower equity brand benefits comparatively more than then higher equity partner. In a series of studies, Levin and colleagues highlight the potential transfer of consumer affect from a high quality brand to a low quality brand (Levin et al., 1996; Levin and Levin, 2000, Levin, 2002). Washburn et al. (2004) suggests that when consumer co-branding partners are at different equity levels, the lower brand benefits more from the alliance because it has more upward potential 
than the stronger partner. Therefore, we hypothesise that the contribution (i.e., added value as a result of an alliance) of a lower ranked university to a single degree offered by a higher ranked university will be lower compared to the corresponding contribution of a higher ranked university to a single degree offered by a lower ranked university. This leads to:

$\mathrm{H}_{2}$ : Perceptions of the added value of a dual degree between the higher (context) - lower (partner) are lower than those for the lower (context) - higher (partner).

\section{Method}

\subsection{Research Design}

This research takes an experimental approach in order to provide comparable information of value perceptions from a single (degree awarded by the context university) and a dual award (a similar degree awarded jointly by the context and partner universities). Differences in value perceptions between the single and dual degrees represent the incremental contribution of the brand alliance. Two studies are undertaken: study 1 tests the added value of a high ranked context university with a lower ranking partner $\left(\mathrm{H}_{1 \mathrm{a}}\right)$, and study 2 tests the added value of a low ranked university with a higher ranked partner $\left(\mathrm{H}_{1 \mathrm{~b}}\right)$. Data from both studies are used to test $\mathrm{H}_{2}$. The UK educational domain represents the research setting and, at the time of the studies, official statistics listed 161 Universities (https://www.hesa.ac.uk/component/heicontacts/). Creating brand alliances between all universities is not feasible and therefore simplification is sought through cluster analysis using information from the widely accepted The Guardian University League Table 2015 guide (http://www.theguardian.com/education/ng-interactive/2014/jun/02/university-league-tables2015-the-complete-list). The position of each university in the table is based on the following criteria: satisfaction with the course; satisfaction with teaching; satisfaction with feedback; student to staff ratio; spend per student/10; average entry tariff; value added score/10; and career after 6 months. Devised as a composite score, ranking reflect the reputation/brand equity of the subject universities. 
Cluster analysis is applied to overall university rather than subject specific data as a mechanism for creating homogeneous ranking groupings. Using the Calinski/Harabasz pseudo-F (the largest pseudo-F value) and Duda/Hart (large Je(2)/Je(1) and small pseudo-T-squared values) as the stopping rules, Table 1 indicates a 10 cluster solution. Multiple comparisons of the clustering criteria lead to a seven cluster simplification (the maximum number of sub-grouping for any criterion was seven). Universities within a cluster have similar attribute profiles and cluster membership denotes universities with high level of brand fit.

Table 1 here

Table 2 provides information of cluster size and indicative membership. Clusters 1 and 7 represent universities with the correspondingly highest and lowest scores in The Guardian criteria and in the remainder of this paper we use the term 'rank' instead of 'cluster'.

Table 2 here

For study 1, respondents were initially asked to review the list of universities in rank 1 and select the most familiar - the context university. The following statement was inserted prior to inviting answers to questions related to the expected value of the (single) degree from the context university: 'We would like you to consider the value of getting a degree from < name of the context university>'. The responses represent perceptions for the single degree.

In order to form the dual degree scenario, respondents were then randomly directed to one of the seven ranks and asked to select the most familiar university (note: if a respondent was assigned rank 1 the originally selected context university was excluded from the list). Prior to answering questions related to the value of the dual degree the following statement appeared: 'Imagine that <name of the context university> and <name of the partner university> are working together to offer a joint honours degree. The degree course will be innovative, interdisciplinary and will utilise the resources of both universities. We would like you to think about the added (or reduced) value of such a joint degree programme, compared to the single degree from < name of the context university >'. The process was repeated for another randomly selected rank. In summary, each 
respondent provided answers to a single degree awarded from the context rank 1 university and similar dual degrees between the context and partner universities randomly selected from two of the seven ranks. In this respect all answers are 'anchored' on a university from rank 1 . In study 2 , the process above was then replicated with a different sample using a rank 7 university as the context university.

\subsection{Sampling, data collection and measures and measurements}

To ensure familiarity, the population comprises individuals enrolled in or completed (within a period of three years prior to this study) a degree (undergraduate or postgraduate) from a UK university. Using an appropriate sampling frame from a specialist list broker, the data were collected through a web-based self-completion survey (Dillman, Smyth and Christina, 2009). Table 3 shows that the samples of the two studies are broadly comparable and confirms that minimum analytical requirements are met.

Table 3 here

The value dimensions are operationalised using scales developed specifically for the educational context and whose psychometric properties are confirmed in previous studies (Ledden et al., 2007 and 2011). Appendix 1 contains the wording of the items for single degree and dual (brand alliance) degrees. For a single degree we use 0 (strongly disagree) to 10 (strongly agree). For the added value of dual degrees, we ask identical questions, with a scale of 0 to -10 (for worse than the context university alone) and 0 to +10 (for better than the context university alone). The single degree measures set the benchmark which is adjusted up (value is added) or down (value is destroyed) for the joint degree offering. Hence the potential value range for the joint degree spans from a worst case of -10 (for a single degree originally scored 0 , less 10 for destroyed value) to a best case of +20 (for a single degree originally scored at 10 , plus 10 for added value).

\section{Analysis}




\subsection{Testing $H_{1 a}$}

Table 4 confirms the psychometric properties of the measures from study 1 (Fornell and Larcker, 1981). The CR (reliability) and AVE (convergent validity) values are correspondingly greater than 0.70 and 0.50 and the diagonal values are notably greater than the bivariate correlations (discriminant validity). We apply one-way MANOVA with planned contrasts treating a single degree (no brand alliance) as control. We achieve equivalence between single and dual degrees though random sampling of replies to a single degree. At the multivariate level the results show significant differences (Wilk's lambda $=.544, \mathrm{~F}=3.05, \mathrm{df}=42,922$, sig. $=.000$ ) with all dimensions individually contributing to the results.

Table 4 here

Figure 1 presents the results of the planned contrasts and the patterns show considerable variation between the value dimensions. We discuss each dimension from the perspective of a rank 1 university. For functional value a brand alliance with another rank 1 university makes a positive contribution to the corresponding value of a single degree while an alliance with a rank 7 university is detrimental. All other alliances have no significant effect on perceptions of functional value from a single degree awarded by a rank 1 university. For the emotional and time dimensions of value perceptions are significantly enhanced when offering a dual degree with universities ranked 1 or 2 while all other collaborations make no significant contribution to a single degree. Increases in emotional value imply higher emotional benefits while those for time indicate willingness to sacrifice time-spend on leisure and family activities. The epistemic and image dimensions share similar patterns. Dual degrees with rank 1 to 4 universities significantly enhance perceptions of value while collaborations with rank 5 to 7 universities make no significant contribution to a single degree offered by a rank 1 university. For social value we observe significant contributions to a single degree by universities ranked 1 to 5 with the lower two ranks making no significant impact on perceptions of a single degree. Similar to functional, the pattern of mean values for monetary 
sacrifice shows that additional monetary burden is justified only in the case of dual degrees with another rank 1 university.

Figure 1 here

\subsection{Testing $H_{1 b}$}

The same analytical approach is applied for $\mathrm{H}_{1 \mathrm{~b}}$. Table 5 confirms the psychometric properties of the measures and we find significant differences at multivariate level of analysis (Wilk's lambda $=.673, \mathrm{~F}=2.01, \mathrm{df}=42,955$, sig. $=.000)$ with all value dimensions contributing individually to the results (Table 7).

\section{Table 5 here}

The pattern of the planned comparisons in Figure 2 shows uniformity across all the value dimensions. Dual degrees between a rank 7 university and those ranked 6 or 7 do not significantly improve perceptions of value across any of the dimensions, while dual degrees with universities ranked 1 to 5 make positive contributions over a single degree. A brand alliance with rank 1 university makes the greatest positive contribution across all dimensions to the corresponding value of a single degree, but is also seen as requiring the greatest time and money sacrifices. Interestingly, alliances with rank 2 universities make a smaller positive contribution to the single degree than alliances with a rank 3-5 university for functional, emotional, epistemic and image value. Social value followed a similar pattern, with alliances with rank 4 or 5 institutions providing greater added value than rank 2 or 3 universities. For time and money sacrifices, the pattern of mean values show an alliance with rank 2 provides less added value to single degree than ranks 3-5, although the difference between rank 2 and 3 for time sacrifices was not significant.

Figure 2 here

\subsection{Testing $\mathrm{H}_{2}$}

We apply independent tests of means to perceptions of added value of dual degrees between universities ranked 1-and-7 (study 1) and 7-and-1 (study 2). Table 6 shows significant differences 
in the predicted direction for all the value dimensions. The greatest difference is in social value, followed by (in order): functional, emotional, image and epistemic value. A greater time sacrifice is perceived than money. Respondents evaluating a low rank single degree (context) perceive greater added value/sacrifices for a dual degree between the context and a high rank partner than respondents evaluating a high rank context who partners with a low rank university for the dual degree.

Table 6 here

\section{Discussion and implications}

This study responds to a lack of empirical research relating to HE branding and, specifically, to the absence of insight into dual degrees offered by two (or more) universities. Conceptualising dual degrees as brand alliances, the research is embedded in attitude accessibility and signalling theories and considers evidence of added value over a single degree as a characteristic of a successful brand alliance. University rankings are treated as proxies for brand equity, the study takes a customer value perspective of brand alliances and by focusing on perceptions of added value rather than equity outcomes, the results capture a broader range of product utility and needs fulfilment. The study considers each dimension of customer value independently. Such a disaggregated approach is a more realistic presentation of customer attitudes, and aligns with recent papers that take a multidimensional view of brand perceptions (Berthon, Holbrook, Hulbert \& Pitt 2007; Cho, Fiore \& Russell, 2015). Parallel examination of dual degrees initiated by highest and lowest ranked universities with collaborating universities at multiple rank levels and partitioning evaluations into constituent criteria add to the novelty of the study, and demonstrates the importance of using multi-dimensional approaches to measuring value perceptions.

The research broadly shows that the added value of a dual degree by a high (low) ranked context university decline (increase) in line with the ranking of a lower (higher) ranked partner university, supporting $\mathrm{H}_{1 \mathrm{a}}$ and $\mathrm{H}_{1 \mathrm{~b}}$. The findings are consistent with past research finding that 
partner brand equity influences perceptions of the brand alliance (Ahn, Kim \& Forney 2009; Besharat 2010, Washburn et al., 2000; 2004). The results reveal differing relationships between university equity levels (i.e., rankings) and specific value dimensions (e.g., functional, emotional, money). Across all criteria for dual degrees initiated by a lowest ranked university, collaborations with universities ranked 5 or higher resulted in perceptions of added value significantly higher to those of a single degree offered by the initiating university or a dual degree with a university ranked 6 or 7. There is asymmetry in the results from a dual degree initiated by a highest ranked university. Three pattern groups are identified. For the functional and money dimensions, added value to a single degree is generated only through alliances with another rank 1 university (singular alliance). Dual degrees between the two highest ranked universities are perceived as having the capacity to deliver utilitarian added value. Students perceive the combined effects of two top ranked universities makes a positive contribution to job prospects (functional) and are willing to make greater monetary sacrifices (money) to achieve such future benefits. Collaborations with universities ranked 1 or 2 result in positive contributions to perceptions of a similar single degree for emotional and time dimensions, which represent elements of value intrinsic to the student. Compared to utilitarian benefits, dual degrees with a wider rank spectrum of university partners lead to increased pride and self-belief perceptions (emotional) and appreciation for the need for greater investment in study time and willingness to sacrifice socialisation activities (time). Dual degrees with the widest rank spectrum (ranked as low as 4 or 5) of partner universities generate perceptions of added value for the epistemic, social and image dimensions. Dual degrees between high to middle ranked universities (ranks 1 through 4) enhance perceptions of knowledge acquisition (epistemic), referent endorsement (social) and reputational association (image) which collectively denote benefits related to personal status.

The study finds that the added benefit of a brand alliance partnership is greater for the lower ranked brand than the higher ranked one $\left(\mathrm{H}_{2}\right)$. For a low rank university, partnering with another low ranked university provides no added value over a single degree. Perceptions of added-value of 
a dual degree between low (context)-high (partner) are significantly higher to those between high (context)-low (partner) ranked universities. In contrast to order effects theory ( $\mathrm{Li}$ and $\mathrm{He}, 2013)$ these findings do not suggest added value is necessarily dictated by the context brand. Research on asymmetrical brand alliances indicates that the weaker equity partner benefits more from an alliance (Kalafatis et al., 2012; Levin and Levin, 2000). The results reveal substantive added value for the context university which joins with a high ranked partner, particularly functional value and social value. This is intuitively appealing. Few potential students possess knowledge of a university degree beyond ranking (e.g. Southampton is a 'top' institution), location and basic programme content, which often appears identical to other institutions. The lack of information about the quality of the dual degree and difficulty in assessing less tangible aspects of value (e.g. epistemic) suggest that greater weight will be placed on potential career opportunities and reputational benefits coming from the high ranked university.

In addition to addressing an overlooked area of research, brand alliances between universities, evidence of interaction effects between brand equity (rank position) of the alliance initiator and evaluation criteria extends knowledge in the general brand alliance literature. Examination of the results between high-high and low-low pairings strengthens the proposed moderating effects of brand equity. The literature offers unequivocal support for the positive impact of brand fit on evaluations of brand alliances (Bluemelhuber et al., 2007; Lafferty, 2007; Lafferty, Goldsmith and Hult, 2004; Simonin and Ruth, 1998). The resulting prediction that dual degrees between similarly high or low ranked universities result in significantly added value over corresponding single degrees is supported only for high ranked universities (moderation effects). The differential contribution of the evaluation criteria to the added value of a brand alliance (confounding effects) confirms concern over the application of unidimensional or overall measures of brand alliances and supports the disaggregate approaches by James et al. (2006) and Kalafatis et al. (2014). An unplanned outcome is the alignment of specific dimensions of value: functional with money, 
emotional with time and epistemic with social and image (Bennett and Ali-Choudhary, 2009, propose a broadly comparable classification).

The findings also inform practice. For the lowest ranked universities the determining factor is the rank position of the collaborating university rather than the value proposition(s) of the dual degree, and the findings discourage the pursuit of such qualifications. Dual degrees in collaboration with similarly ranked universities are unlikely to generate perceptions of added value compared to single degrees irrespective of the value proposition and therefore will not attract students. Unless there are specific complementary strengths, it is unlikely that lowest ranked universities will obtain agreement by significantly higher ranked universities to embark on a joint qualification.

The results offer encouragement to dual degrees initiated by the highest ranked universities and provide guidance in partner selection. Alliances with equal rank universities is the recommended option for dual degrees based on functional benefits (e.g., career advancement or financial). When the focus is intrinsic benefits (e.g., emotional) dual degrees between similarly perceived partner universities can deliver added value. Dual degrees with an extended range of partners (all but the lowest ranked universities) deliver added value related to personal status (e.g., self-belief and social acceptance). Although this study examines name order effects only between the highest and lowest rank universities, the findings suggest that it would be wise for the highest ranked university to appear first, regardless of the level of partner. This is consistent with predictions of signalling theory where a highly ranked institution would not embark on a dual degree of questionable quality due to the potential negative reputational consequences.

The following limitations frame the findings and offer opportunities for further research. The findings are predicated on the assumption that rankings are analogous to brand equity and the application of a specific type of cluster analysis on a single set of data. Confirmation of the results is needed though application of different brand equity measures and implementation of diverse clustering approaches on alternative (league) tables. The assumed equivalence of universities within a specific cluster needs to be tested. Further research should consider the impact of 
governmental activities and legislation (e.g., differential fees and student repayment schemes). The impact of relationship marketing activities (e.g., efforts to build brand associations, individual and shared experiences) on value perceptions is under-researched (Sirdeshmukh, Singh \& Sabol, 2002) and should be considered. The presence of confounding effects due to lack of differentiation between subject areas and types of degrees merits further attention. Surveying students who selected a dual in preference to a single degree will confirm the external validity of the findings. The calibration of the results for brand alliances initiated by universities in intermediate (i.e., not 1 or 7) rank groups will provide further insight. Future studies could include explicit measures of brand fit between the collaborating universities and examine spill-over effects. The focus on the UK HE educational domain limits the generalisability of the results. International joint degrees have been encouraged by policy makers as "a core tool for institutional development" and a "huge opportunity to foster mobility and facilitate the strategic positioning of institutions and networks" (Tauch, 2005). Inclusion of dual degrees between UK and overseas universities is an important area for future research. Recent studies have highlighted the importance of country image fit to brand alliance perceptions (Lee, Lee and Lee, 2013; Li and He 2013), particularly where brand familiarity is low (Bluemelhuber, Carter and Lambe, 2008). Given the paucity of supply-side research (Gammoh and Voss 2013; Newmeyer, Venkatesh \& Chatterjee, 2013), future studies could look at value drivers from a university perspective. Finally, confirmatory research is needed for the proposed alignment of the value dimensions under the utilitarian (functional and money), extrinsic (emotional and time) and personal status (epistemic, social and image) classifications. 


\section{References}

Aaker, J.L. (1997). Dimensions of brand personality. Journal of Marketing Research, 34: 347-356.

Ahn, S., Kim, H. \& Forney, J.A. (2009) Co-marketing alliances between heterogeneous industries: examining perceived match-up effects in product, brand and alliance levels. Journal of Retailing and Consumer Services, 16: 477-485.

Anderson, N.H. (1981). Foundations of Information Integration Theory. Academic Press: New York.

Anderson, J.R. \& Bower, G.H. (1973). Human Associative Memory. V. H. Winston \& Sons: Oxford

Babin, B.J. \& James, K.W. (2010). A brief retrospective and introspective on value. European Business Review, 22:471-478.

Bennett, R. \& Ali-Choudhury, R. (2009). Prospective students' perceptions of University brands: An empirical study. Journal of Marketing for Higher Education, 19:85-107.

Berthon, P., Holbrook, M.B., Hulbert, J.M. \& Pitt, L. (2007). Viewing brands in multiple dimensions. MIT Sloan Management Review, 48(2): 37-43.

Besharat, A. (2010). How co-branding versus brand extensions drive consumers' evaluations of new products: a brand equity approach. Industrial Marketing Management, 39(8):1240-1249.

Bluemelhuber, C., Carter, L. L., \& Lambe, C. J. (2007). Extending the view of brand alliance effects: An integrative examination of the role of country of origin. International Marketing Review, 24(4):427-443.

Bouten, L.M., Snelders, D. \& Hultink, E.J. (2011). The impact of fit measures on the consumer evaluation of new co-branded products. Journal of Product Innovation Management, 28(4):455469.

Brookes, M. (2003). Higher education: Marketing in a quasi-commercial service industry. International Journal of Nonprofit and Voluntary Sector Marketing, 8(2):134-142.

Bunzel, D. (2007). Universities sell their brands. Journal of Product and Brand Management, 162):152-153.

Carvalho, S.W. \& Mota, M.de O. (2010). The role of trust in creating value and student loyalty in relational exchanges between higher education institutions and their students. Journal of Marketing for Higher Education, 20:145-165.

Chan, K.O. \& Cheng, S. (2012). Consumer perceptions of branding alliances of educational institutions and hotels in Hong Kong. International Journal of Business and Management, 7(21): 92-105.

Chapleo, C. (2010a). What defines "successful" university brands? International Journal of Public Sector Management, 23(2):169-183.

Chapleo, C. (2010b). Branding a university?; adding real value or 'smoke and mirrors'?, In: M. Molesworth, R Scullion \& E. Nixon (eds). The Marketisation of Higher Education and Students as Consumers, pp. 101-114, Routledge: London

Chapleo, C. (2011). Exploring rationales for branding a university: Should we be seeking a measure of branding in UK universities? Journal of Brand Management, 18(6):411-422.

Cho, E., Fiore, A.M. \& Russell, D.W. (2015). Validation of a Fashion Brand Image Scale Capturing Cognitive, Sensory and Affective Associations: Testing its Role in an Extended Brand Equity Model. Psychology \& Marketing, 32(1): 28-48. 
Chung, E., \& McLarney, C. (2000). The classroom as a service encounter: suggestions for value creation. Journal of Management Education, 24:484-500.

Cunha, M.C. Jr., Forehand, M.R. \& Angle, J.W. (2015). Riding coattails: When co-branding helps versus hurts less-known brands. Journal of Consumer Research, 41(5):000-000.

Curtis T., Abratt, R \& Minor, W. (2009). Corporate brand management in higher education: The case of ERAU. Journal of Product and Brand Management, 18(6):404-413.

Delgado-Ballester, E. \& Hernandez-Esallardo, M. (2008). Building online brands through brand alliances in internet. European Journal of Marketing, 42(9/10):954-976.

Desai, K.K. \& Keller, K.L. (2002). The effects of ingredient branding strategies on host brand extendibility. Journal of Marketing, 66(1):73-93.

Dillman, D.A., Smyth, J.D. \& Christina, L.M. (2009). Internet, Mail, and Mixed-mode Surveys: The Tailored Design Method. $3^{\text {rd }}$ ed., John Wiley \& Sons:Hoboken, NJ

Doyle, P. \& Stern P. (2006). Marketing Management and Strategy, $4^{\text {th }}$ ed., Prentice Hall:Harlow

Erevelles, S., Horton, V. \& Fukawa, N. (2008). Understanding B2C brand alliances between manufacturers and suppliers. Marketing Management Journal, 18(2):32-46.

Fang, X., and Misra, S. (2002). The effect of brand alliance portfolio on the perceived quality of an unknown brand. Advances in Consumer Research, 29:519-520.

Fang, X., Gammoh, B.S. \& Voss, K.E. (2013). Building brands through brand alliances: combining warranty information with a brand ally. Journal of Product \& Brand Management, 22(2): 153160.

Fazio, R.H. (1986). How do attitudes guide behaviour? In J.R.M. Sorrentino \& E.T. Higgins (Eds.).Handbook of motivation and cognition, 1:204-243. New York: Guilford Press.

Fornell, C. \& Larcker, D.F. (1981). Evaluating structural equation models with unobservable variables and measurement error. Journal of Marketing Research, 18(1):39-50.

Gammoh, B.S. \& Voss, K.E. (2013). Alliance competence: the moderating role of valence of alliance experience. European Journal of Marketing, 47(5/6): 964-986.

Galli, M. \& Gorn, G. (2011). Unconscious transfer of meaning to brands. Journal of Consumer Psychology, 21(3): 215-225.

Gammoh, B.S., Voss, K.E. \& Chakraborty, G. (2006). Consumer evaluation of brand alliance signals. Psychology \& Marketing, 23(6): 465-486.

Gibbs, P. (2002). From the invisible hand to the invisible hand shake - marketing higher education. Research in Post-Compulsory Education, 7(3):323-335.

Gibbs, P. (2007). Marketing and education - A class or a synergy in time? Journal of Business Research, 60:1000-1002.

Gray, J. B., Fam, S. K., \& Llandes, A. V. (2003). Branding universities in Asian markets. Journal of Product Brand Management, 12(2):108-120.

Hemsley-Brown, J. \& Goonawardana, S. (2007). Brand harmonization in the international higher education market. Journal of Business Research, 60:942-948.

Hemsley-Brown, J. \& Oplatka, I. (2006). Universities in a competitive global marketplace. International Journal of Public Sector Management, 19(4):316-338.

Helmig, B., Huber, J. A. \& Leeflang, P. S. H. (2008) Co-branding: The State of the Art. Schmalenbach Business Review, 60, October, 359-377. 
Hillyer, C. \& Tikoo, S. (1995). Effect of cobranding on consumer product evaluations. Advances in Consumer Research, 22: 123-127.

Houston, D.A. \& Fazio, R.H. (1989). Biased processing as a function of attitude accessibility: making objective judgments subjectively. Social Cognition, 7(Spring):51-66.

Huber, J-A. (2005). Co-Branding als Strategieoption der Marken politik, Wiesbaden: Gabler.

James, D., Lyman. M. \& Foreman, S.K. (2006). Does the tail wag the dog? Brand personality in brand alliance evaluation, Journal of Product \& Brand Management, 15(3):173-183.

Journal of Marketing for Higher Education (2014), Special Issue on Branding in Higher Education, 24(1).

Kalafatis, S., Remizova,, N. Riley, D. and Singh, J. (2012). The differential impact of brand equity on B2B co-branding," Journal of Business and Industrial Marketing, 27(8): 623-634.

Kalafatis, S.P. Riley, D. \& Singh, J. (2014). Context effects in the evaluation of business-tobusiness brand alliances. Industrial Marketing Management, 43:322-334.

Keller, K.L. (1993). Conceptualizing, measuring and managing customer-based brand equity. Journal of Marketing, 57(1):1-22.

Keller, K.L. (2003). Brand synthesis: the multidimensionality of brand knowledge. Journal of Consumer Research, 29(4):595-600.

Khanna, M., Jacob, I. \& Yadav, N (2014, Identifying and analyzing touchpoints for building a higher education brand. Journal of Marketing for Higher Education, 24(1):122-143.

Kirmani, A. \& Rao, A.R. (2000). No pain, no gain: A critical review of the literature on signaling unobservable product quality. Journal of Marketing, 64(2):66-79.

Lafferty, B.A. (2007). The relevance of fit in a cause-brand alliance when consumers evaluate corporate credibility. Journal of Business Research, 60(5):447-453.

Lafferty, B.A., Goldsmith, R.E., \& Hult, G.T. M. (2004). The impact of the alliance on the partners: A look at cause-brand alliances. Psychology and Marketing, 21(7):509-531.

Lebar, E., Buehler, P., Keller, K.L., Sawicka, M. Aksehirili, Z., \& Keith, R., (2005). Brand equity implications of joint branding programs. Journal of Advertising Research, 45(4): 413-425.

Ledden, L., Kalafatis, S.P. \& Mathioudakis, A. (2011). The idiosyncratic behaviour of service quality, value, satisfaction and intention to recommend in Higher Education: An empirical examination. Journal of Marketing Management, 27(11-12):1232-1260.

Ledden, L., Kalafatis, S.P. \& Samouel, P. (2007). An empirical examination of the relationship between personal values and perceived value of education. Journal of Business Research, 60(9):965-974.

Lee, J.K., Lee, B-K. \& Lee, W-N. (2013) Country-of-origin fit's effect on consumer product evaluation in cross-border strategic brand alliance. Journal of Business Research, 66(3):354-363.

Levin, A. (2002). Contrast and assimilation processes in consumers' evaluations of dual brands. Journal of Business and Psychology, 17(1): 145-154.

Levin, A. M., Davis, J. C., \& Levin, I. P. (1996). Theoretical and empirical linkages between consumers' responses to different branding strategies. In K. Corfman, \& J. Lynch (Eds.). Advances in Consumer Research, (pp. 296-300). Association for Consumer Research, Provo, UT, 23.

Levin, I. P., \& Levin, A. M. (2000). Modeling the role of brand alliances in the assimilation of product evaluations. Journal of Consumer Psychology, 9(1): 43-52. 
Li, Y. \& He, H. (2013). Evaluation of international brand alliances: Brand order and consumer ethnocentrism. Journal of Business Research, 66(1): 89-97.

McCarthy, M.S. \& Norris, D.G. (1999). Improving competitive position using branded ingredients. Journal of Product \& Brand Management, 8:267-283.

Melewar, T.C. \& Akel, S. (2005). The role of corporate identity in the higher education sectors: A case study. Corporate Communications: An International Journal, 10(1):41-57.

Miller, J.M. \& Krosnick, J.A. (1998, The impact of candidate name order on election outcomes. The Public Opinion Quarterly, 62(3):291-330.

Molesworth, M., Nixon, E. \& Scullion, R. (2009). Having, being and higher education: the marketisation of the university and the transformation of the student into consumer. Teaching in Higher Education, 14:277-287.

Newmeyer, C.E., Venkatesh, R. and Chatterjee, R. (2014). Cobranding arrangements and partner selection: a conceptual framework and managerial guidelines. Journal of the Academy of Marketing Science, 42(2):103-118.

Ng, I.C.L. \& Forbes, J. (2009). Education as service: the understanding of university experience through the service logic. Journal of Marketing for Higher Education, 19:38-64

Norris, D.G. (1992). Ingredient branding: a strategy option with multiple beneficiaries. Journal of Consumer Marketing, 9(3):19-31.

Norris, D.G. (1993). Intel inside: branding a component in a business market. Journal of Business and Industrial Marketing, 8(1):14-24.

Park, C. W., Jun, S.Y., \& Shocker, A. D. (1996). Composite branding alliances: an investigation of extension and feedback effects. Journal of Marketing Research, 33(4):453-466.

Park, C.W., Milberg, S. \& Lawson , R. (1991) Evaluation of brand extensions: the role of product feature similarity and brand concept consistency. Journal of Consumer Research, 18(2):185-193.

Pinar, M., Trapp, P., Girard, T. \& Boyt, E.T. (2011). Utilizing the brand ecosystem framework in designing branding strategies for higher education. International Journal of Educational Management, 25(7):724-739.

Rao, A. R., \& Ruekert, R. W. (1994). Brand alliances as signals of product quality. Sloan Management Review, 36(1):87-97.

Rao, A. R., Qu, L., \& Ruekert, R. W. (1999). Signaling unobservable product quality through a brand ally. Journal of Marketing Research, 36(2):258-268.

Samu, S., Krishnan, H.S. \& Smith, R.E. (1999). Using advertising alliances for new product introduction: interactions between product complementarity and promotional strategies. Journal of Marketing, 63: 57-74.

Sánchez-Fernández, R. \& Iniesta-Bonillo, M.Á. (2007). The concept of perceived value: A systematic review of the research. Marketing Theory, 7:427-451.

Sánchez-Fernández, R. \& Iniesta-Bonillo, M.Á. (2009). Efficiency and quality as economic dimensions of perceived value: conceptualisation, measurement, and effect of satisfaction. Journal of Retailing and Consumer Services, 16:425-433.

Simonin, B. L. \& Ruth, J. A. (1998). Is a company known by the company it keeps? Assessing the spillover effects of brand alliances on consumer brand attitudes. Journal of Marketing Research, 35(February):30-42.

Sirdeshmukh, D., Singh, J. \& Sabol, B. (2002). Consumer trust, value and loyalty in relational exchanges. Journal of Marketing, 66(1): 15-37. 
Tauch, C. (2005), 'The Bologna Process: state of implementation and external dimension' in Muche, F. (ed.), Opening up to the Wider World: The External Dimension of the Bologna Process, ACA Papers on International Cooperation in Education, Bonn, Lemmens Verlags- \& Mediengessellschaft.

Vaidyanathan, R. \& Aggarwal, P. (2000). Strategic brand alliances: implications of ingredient branding for national and private label brands. Journal of Product \& Brand Management, 9:214-228.

Venkatesh, R. \& Mahajan, V. (1997). Products with branded components: an approach to premium pricing and partner selection. Marketing Science, 16(2):146-165.

Votolato, N.L. \& Unnava, H.R. (2006). Spillover of negative information on brand alliances. Journal of Consumer Psychology, 16(2):196-202.

Voss, K.E. \& Gammoh, B.S. (2004). Building brand through brand alliances: does a second ally help? Marketing Letters, 15(2/3):147-159.

Wæraas, A. \& Solbakk, N.M. (2009). Defining the essence of a university: Lessons from higher education branding. Higher Education, 57:449-462.

Washburn, J.H., Till, B.D. \& Priluck, R. (2000). Co-branding: brand equity and trial effects. Journal of Consumer Marketing, 17(7):591-604.

Washburn, J.H., Till, B.D. \& Priluck, R. (2004). Brand alliance and customer-based brand-equity effects. Psychology \& Marketing, 21(7):487-508.

Woodall, T. (2003). Conceptualising 'value for the customer': An attributional, structural and dispositional analysis. Academy of Marketing Science Review, 1-31.

Zeithaml, V.A. (1988). Consumer perceptions of price, quality and value: a means-end model and synthesis of evidence. Journal of Marketing, 52:2-22. 


\section{Appendix 1 - Operationalisations of the value dimensions}

\section{Functional}

No brand alliance - Getting a degree from $<$ University $\mathrm{X}>$ will:

Brand alliance - Think about getting a joint degree from $\langle$ University $\mathrm{X}\rangle$ and $\langle$ University $\mathrm{Y}\rangle$ as compared to a degree from $<$ University $X>$ alone. For each of the benefits below, would the joint degree be better or worse than the single degree?

- allow me to earn a good salary

- allow me to achieve my career goals

- lead to promotion in my current/future job

- represent investment in my future

- contribute to my personal development

\section{Epistemic}

No brand alliance - During my studies at <University X>, I expect that:

Brand alliance - Compared to a degree from $<$ University $X>$ alone, during my studies for a joint degree from $\langle$ University $\mathrm{X}\rangle$ and $\langle$ University $\mathrm{Y}\rangle$, I expect that:

- the content of a course will keep me interested

- to learn new things on the course

- the content of a course will contribute greatly to my education

- valuable input from the lecturers and other academic staff

\section{Social}

No brand alliance - Obtaining a degree from $\langle$ University $X>$ will be viewed positively by:

Brand alliance - Compared to a degree from $\langle$ University $\mathrm{X}\rangle$ alone, obtaining a joint degree from $<$ University $\mathrm{X}>$ and <University $\mathrm{Y}>$ will be viewed positively by:

- people who are important to me

- people who influence what I do

- my current/future employer

- my family and friends

\section{Emotional}

No brand alliance - Getting a degree from $\langle$ University $\mathrm{X}\rangle$ will:

Brand alliance - Compared to a degree from $<$ University $X>$ alone, getting a joint degree from

$<$ University $\mathrm{X}>$ and $<$ University $\mathrm{Y}>$ will:

- make me feel proud

- boost my confidence

- fulfil an ambition

- given me a sense of self-achievement

\section{Image}

No brand alliance - Considering the image of $\langle$ University $\mathrm{X}\rangle$ :

- The reputation of $\langle$ University $X\rangle$ will increase the value of my degree

- I believe that employers have positive things to say about $\langle$ University $X\rangle$

- I have heard positive things about <University X>

- I believe that $<$ University $\mathrm{X}>$ has a good reputation

Brand alliance - Compared to a single degree from $\langle$ University $X\rangle$ :

- how will the reputation of $\langle$ University $\mathrm{X}\rangle$ and $\langle$ University $\mathrm{Y}\rangle$ affect the value of the joint degree?

- what will employers think about the joint degree between $\langle$ University $\mathrm{X}\rangle$ and $\langle$ University $\mathrm{Y}\rangle$

- what word-of-mouth do you expect to hear about the joint degree?

- what reputation do you think the joint degree will have? 


\section{Time}

No brand alliance - In order to complete a degree from <University $\mathrm{X}>\mathrm{I}$ will need to:

Brand alliance - Compared to a single degree from $\langle$ University $X\rangle$, in order to complete a joint degree from <University $\mathrm{X}>$ and $\langle$ University $\mathrm{Y}>$ I will need to:

- give up some hobbies and pastimes

- reduce the time I spend with my family

- reduce the time I spend with my friends

\section{Money}

No brand alliance

- I will be happy to make financial sacrifices for a degree from $\langle$ University $X\rangle$

- The fees I will have to pay for the degree at $<$ University $X>$ are reasonable

- I believe that the quality of a degree from $\langle$ University $X>$ justifies the expense

- Any student debt incurred studying for a degree from $\langle$ University $X\rangle$ is worth it

Brand alliance - Compared to a degree from <University $\mathrm{X}>$ alone:

- I will be happy to make financial sacrifices for a joint degree from $\langle$ University $X\rangle$ and <University Y>

- the fees I will have to pay for a joint degree at from $\langle$ University $\mathrm{X}\rangle$ and $\langle$ University $\mathrm{Y}\rangle$

- the quality of the joint degree from $\langle$ University $\mathrm{X}\rangle$ and $\langle$ University $\mathrm{Y}\rangle$ will justify the expense.

- the student debt incurred for a joint degree from $\langle$ University $\mathrm{X}\rangle$ and $\langle$ University $\mathrm{Y}\rangle$ will be a good investment. 
Table 1: Cluster solution

\begin{tabular}{|cccc|}
\hline $\begin{array}{c}\text { Number } \\
\text { of clusters }\end{array}$ & $\begin{array}{c}\text { Calinski/Harabasz } \\
\text { clusters pseudo-F }\end{array}$ & \multicolumn{2}{c|}{$\begin{array}{c}\text { Duda/Hart } \\
\text { Pseudo T }\end{array}$} \\
\hline 1 & & 0.3095 & 252.16 \\
2 & 252.16 & 0.3271 & 94.62 \\
3 & 295.35 & 0.4271 & 87.21 \\
4 & 299.77 & 0.3335 & 63.95 \\
5 & 293.86 & 0.4714 & 52.71 \\
6 & 277.17 & 0.3011 & 27.86 \\
7 & 361.77 & 0.3081 & 35.92 \\
8 & 382.49 & 0.2569 & 26.03 \\
9 & 408.75 & 0.4642 & 24.24 \\
10 & $\mathbf{4 3 2 . 5 1}$ & $\mathbf{0 . 6 9 4 5}$ & $\mathbf{1 1 . 4 3}$ \\
11 & 418.55 & 0.4712 & 12.35 \\
12 & 405.80 & 0.7318 & 6.96 \\
13 & 390.55 & 0.6490 & 8.11 \\
14 & 378.25 & 0.6608 & 6.67 \\
15 & 366.52 & 0.4013 & 5.97 \\
\hline
\end{tabular}

Table 2: Number of universities and indicative cluster membership (numbers in each cluster)

\begin{tabular}{|lllllll|}
\hline \multicolumn{1}{|c}{$\begin{array}{c}\text { Cluster } 1 \\
(8)\end{array}$} & \multicolumn{1}{c}{$\begin{array}{c}\text { Cluster } 2 \\
(10)\end{array}$} & \multicolumn{1}{c}{$\begin{array}{c}\text { Cluster } 3 \\
(15)\end{array}$} & \multicolumn{1}{c}{$\begin{array}{c}\text { Cluster } 4 \\
(16)\end{array}$} & $\begin{array}{c}\text { Cluster } 5 \\
(28)\end{array}$ & $\begin{array}{c}\text { Cluster 6 } \\
(19)\end{array}$ & \multicolumn{1}{c|}{$\begin{array}{c}\text { Cluster } 7 \\
(6)\end{array}$} \\
\hline Cambridge & Lancaster & Surrey & Loughborough & Coventry & Northampton & West London \\
Oxford & Exeter & Heriot-Watt & Kent & Derby & Glyndwr & Anglia Ruskin \\
St Andrews & York & UEA & Leicester & Portsmouth & Gloucestershire & London South \\
Imperial & Bath & Birmingham & Aston & Bangor & Middlesex & Bank \\
College & Warwick & Southampton & Reading & UWE Bristol & Staffordshire & Bedfordshire \\
London & Edinburgh & Nottingham & City & Hertfordshire & Roehampton & Bucks New \\
School of & & & & & & University \\
Economics & & & & & & London Met \\
Durham & & & & & & \\
\hline
\end{tabular}


Table 3: Number of replies and sample composition

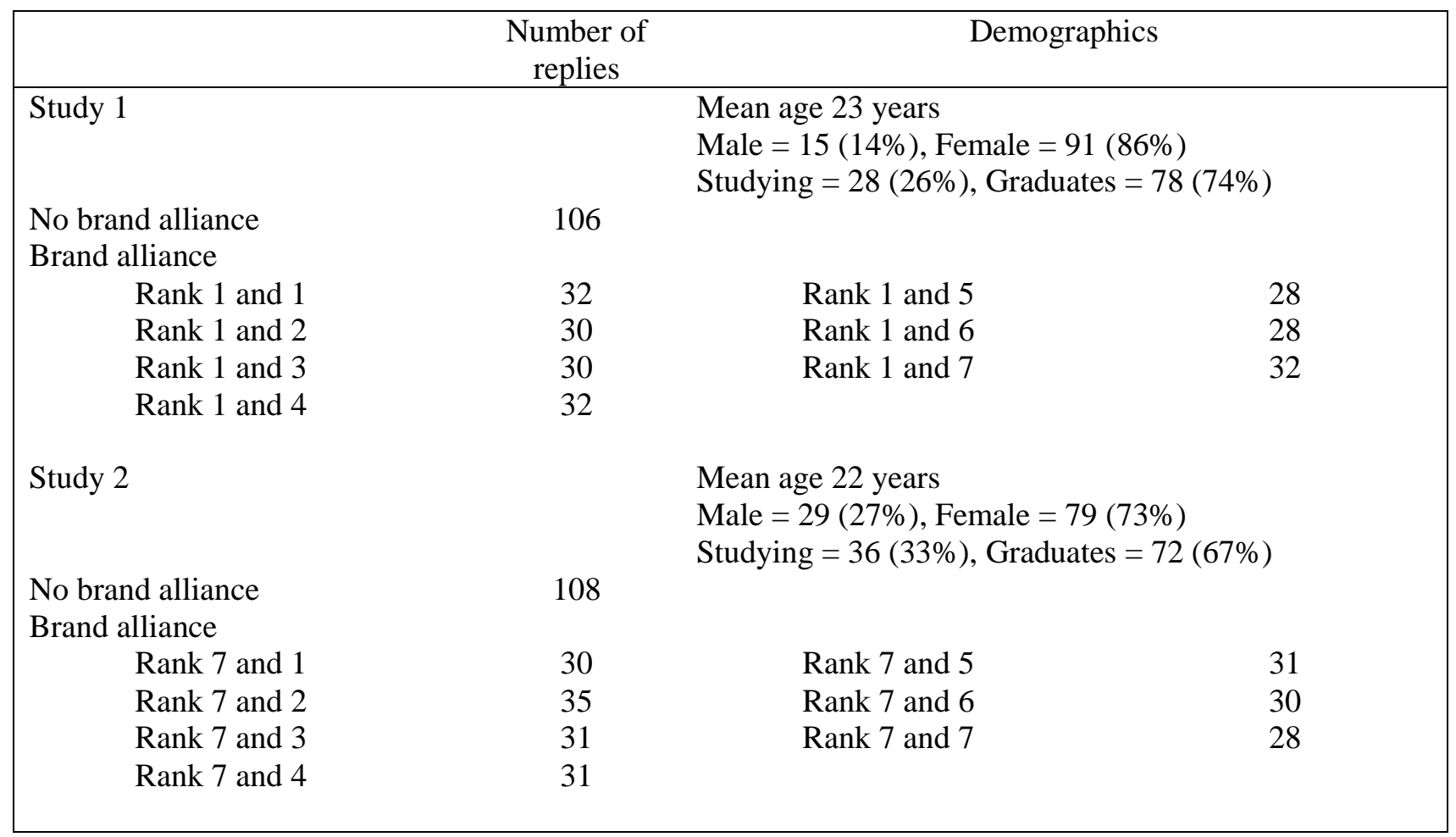

Note: For a medium effect size and power of 0.80 with a level of significance of 0.05 , the required total sample size is 231 (using GPower 3.0 software; Faul, Erdfelder, Lang and Buchner, 2007). This results in 33 observations per experimental condition, which is comparable to the cell sizes.

Table 4: Study 1- Reliability and validity indexes off measure

\begin{tabular}{|c|c|c|c|c|c|c|c|c|c|}
\hline Dimensions of value & $\begin{array}{c}\text { Functi } \\
\text { onal }\end{array}$ & $\begin{array}{c}\text { Emoti } \\
\text { onal }\end{array}$ & $\begin{array}{l}\text { Episte } \\
\text { mic }\end{array}$ & Social & Image & Time & Effort & CR & AVE \\
\hline Functional & .787 & & & & & & & .864 & .620 \\
\hline Emotional & .642 & .764 & & & & & & .848 & .583 \\
\hline Epistemic & .328 & .459 & .811 & & & & & .884 & .657 \\
\hline Social & .600 & .688 & .433 & .725 & & & & .814 & .526 \\
\hline Image & .686 & .590 & .414 & .598 & .834 & & & .899 & .696 \\
\hline Time & .352 & .164 & .153 & .134 & .141 & .788 & & .861 & .621 \\
\hline \multirow[t]{2}{*}{ Money } & .391 & .356 & .089 & .343 & .438 & .466 & .882 & .935 & .788 \\
\hline & \multicolumn{9}{|c|}{ Off diagonal bivariate correlations, diagonal square root of AVE } \\
\hline$F$-value; $d f=6$ & 8.22 & 6.14 & 5.72 & 10.74 & 9.21 & 9.23 & 2.29 & & \\
\hline Sig. & .000 & .000 & .000 & .000 & .000 & .000 & .018 & & \\
\hline
\end{tabular}


Figure 1: Study 1- Planned contrasts
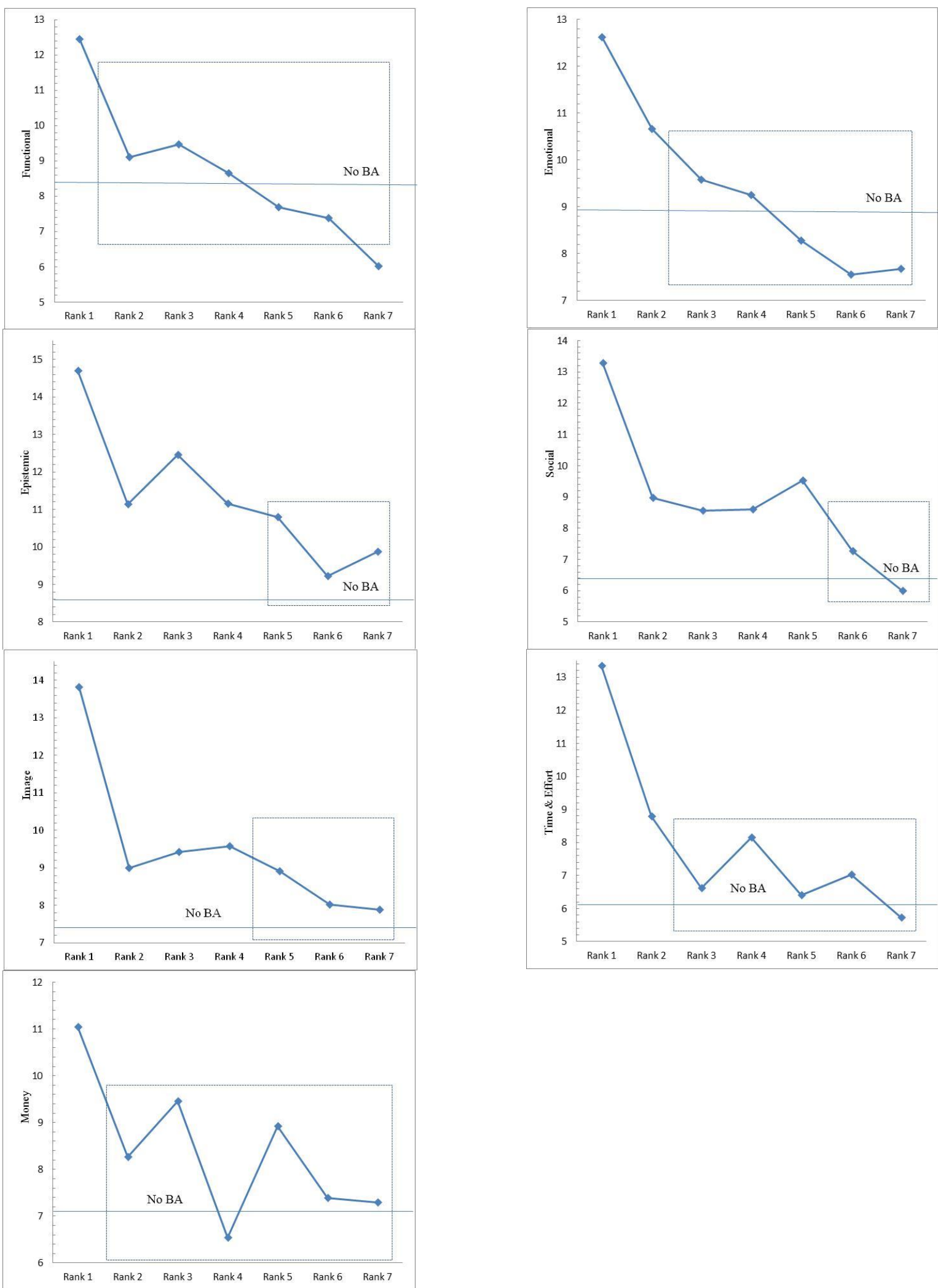

Note: Horizontal lines are mean values of a single degree and boxed areas depict homogeneous groups. 
Table 5: Study 2 - Reliability and validity indexes of measures

\begin{tabular}{|l|ccccccccc|}
\hline Dimensions of value & $\begin{array}{c}\text { Functi } \\
\text { onal }\end{array}$ & $\begin{array}{c}\text { Emoti } \\
\text { onal }\end{array}$ & $\begin{array}{c}\text { Episte } \\
\text { mic }\end{array}$ & Social & Image & Time & Effort & CR & AVE \\
\hline Functional & .857 & & & & & & & .917 & .734 \\
Emotional & .834 & .915 & & & & & & .954 & .838 \\
Epistemic & .670 & .696 & .910 & & & & & .951 & .829 \\
Social & .756 & .831 & .720 & .909 & & & & .950 & .826 \\
Image & .766 & .804 & .571 & .816 & .911 & & & .951 & .831 \\
Time & .517 & .541 & .513 & .582 & .590 & .754 & & .837 & .568 \\
Money & .597 & .646 & .416 & .686 & .779 & .599 & .906 & .948 & .820 \\
& Off diagonal bivariate correlations, diagonal square root of AVE & & \\
$F$-value; $d f=6$ & 5.26 & 6.18 & 4.58 & 6.97 & 4.54 & 5.17 & 5.13 & & .000 \\
Sig. & .000 & .000 & .000 & .000 & .000 & .000 & .000 & \\
\hline
\end{tabular}

Table 6: Comparing rank 1-and-7 with 7-and-1 dual degrees

\begin{tabular}{|c|c|c|c|}
\hline \multirow[t]{2}{*}{ Dimensions of value } & \multicolumn{2}{|c|}{$\begin{array}{l}\text { Mean values } \\
\end{array}$} & \multirow{2}{*}{ t-value, df and sig } \\
\hline & Rank 1 with Rank 7 & Rank 7 with Rank 1 & \\
\hline Functional & 6.02 & 11.01 & $4.18,60, .000$ \\
\hline Emotional & 7.68 & 11.80 & $3.42,60, .000$ \\
\hline Epistemic & 9.38 & 11.56 & $1.71,60, .046$ \\
\hline Social & 5.99 & 11.87 & $4.93,60, .000$ \\
\hline Image & 7.38 & 10.71 & $2.59,60, .006$ \\
\hline Time & 5.22 & 10.78 & $4.09,60, .000$ \\
\hline Money & 7.29 & 11.06 & $2.62,59, .006$ \\
\hline
\end{tabular}


Figure 2: Study 2 - Planned contrasts
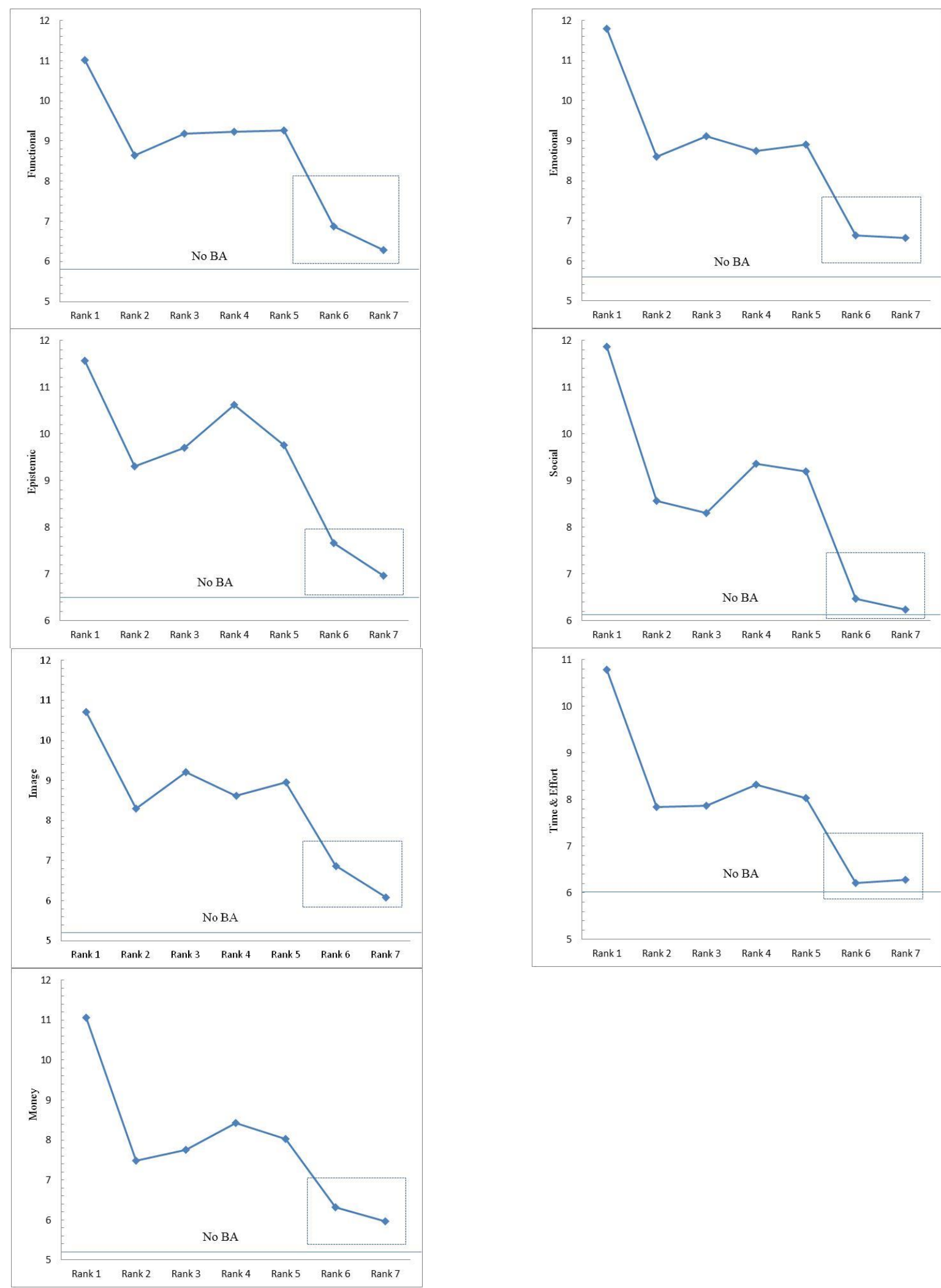

Note: Horizontal lines indicate mean values of a single degree and boxed areas depict homogeneous groups. 